\title{
DIE CHRISTUSGETUIENIS IN DIE OU TESTAMENT - 'N BELYDENISWERKLIKHEID
}

\author{
F.N. Lion-Cachet \\ Departement Ou Testament \\ Potchefstroomse Universiteit vir $\mathrm{CHO}$ \\ POTCHEFSTROOM
}

\begin{abstract}
According to John 5:39 the Old Testament provides a very clear testimony of Christ. Yet Jesus had to explain this Old Testament testimony even to his disciples. These Old Testament references to Christ are currently considered in wider cincles and therefore it may be the appropiate time to examine the testimony on Christ on a basis true to the Scriptures (as fomulated in the articles of faith of the Refonned Churches). A limited investigation of the Old Testament will reveal that cenain acts of the persons of the Trinity may be recognized, that a Messianic expectation exists and that certain promises appear which may only be fulfilled in Christ, and that certain ceremonies, events and persons may be interpreted as a prefiguration of Christ.
\end{abstract}

\section{INLEIDING}

In Johannes 5:39 sê Jesus vir die Jode: "Julle ondersoek die Skrifte, omdat julle meen dat julle daarin die ewige lewe het; en dit is dié wat van My getuig." Jesus is hier aan die woord in 'n diskussie oor sy seunskap (vgl. verse 16-19). Die Jode het die Skrifte noukeurig ondersoek, nagespeur en uitgepluis (vgl. 1 Petr. 1:11). Die "Skrifte" 7 "Skrif" in die 1983-Afrikaanse Vertaling), 'n afgeslote geheel van die Ou Testament, getuig van Hom. Om te getuig beteken om op 'n basis van eerstehandse kennis, soos dié van oog- en oorgetuies, van sekere feite of ondervindinge ' $n$ verklaring of ' $n$ bevestiging uit te spreek (vgl. Strathmann, 1967:496). Na die opstanding het Christus aan die Emmaüsgangers en die elf apostels, Moses (die Tora), die profete en die al die Skrifte (ook die Psalms genoem, dit wil sê die Geskrifte) uitgelê en dié dinge wat op Hom betrekking het, aangetoon (Luk. 24:27 en 44). Wat geskrywe was, moes vervul word (Luk. 24:44). Hier word weer na die Ou Testament in sy driedeling verwys. Dele soos Jesaja 9:5-6; 11:1; $52-53$ en Psalm 22 kan hier in aanmerking geneem word (vgl. Greijdanus, 1955).

Uit bogenoemde is twee dinge duidelik: die Skrifte, dit is die Ou Testament, gee klinkklare getuienis van die Christus, die Seun van God, en tog is dit nodig dat Jesus en die apostels nogeens moet aantoon dat daar wel getuienis oor Hom bestaan. Hoe die Ou Testament van die Christus getuig, moet dus nader verklaar word. Die Woord 
(Christus) was van die begin van die skepping af teenwoordig (Joh. 1:1; Kol. 1:16), of om dit nog beter te sê: Hy was van alle ewigheid af daar (Fil. 2:6-7). Bouma (1950:156) verklaar daarom tereg: "Wie de Schriften leest zonder er Christus in te vinden, zonder er het getuigenis Gods van Christus in te horen leest ze niet goed."

Die Kerke in die gereformeerde tradisie bely die Drie-eenheid (die ekumeniese belydenisse). Die persoon van die Seun is die Woord, die Wysheid en die Beeld van die Vauer (NGB art. 8). Die belydenis van die Drie-eenheid kan op baie plekke in die Ou Testament gegrond word (NGB art. 9; HK vraag en antw. 25). God het ook in die Ou Testament die belofte gegee dat Hy sy Seun, uit 'n vrou gebore, sal gee om die mens salig te maak (NGB art. 17; HK vraag en antw. 19). Daar was verder sekere seremonies en heenwysings van die Wet wat Christus afgebeeld het, maar alle voorafskaduwing het met die koms van Christus tot 'n einde gekom (NGB art. 25).

Die naam van Jesus Christus word egter nie eksplisiet in die Ou Testament genoem nie, alhoewel Vischer (1946:7) opgemerk het dat "(d)en beiden Hauptwörtern des christlichen Bekenntnisses 'Jesus ist Christus', dem Eigennamen 'Jesus' und dem Berufsnamen 'Christus', entsprechen die beide Teile der heiligen Schrift: das Neue und das Alte Testament. Das Alte Testament sagt, was der Christus ist, das Neue wer er ist, ..." In sy werke het Vischer dan ook probeer om hierdie stelling met vers en kapittel aan te toon. Sy geforseerde verklaring word vandag egter algemeen gekritiseer.

Aan die ander kant het die lede van die Nederduits Geformeerde Kerk (TKK, 19821989:628-629) in die tussenkerklike gesprek, versigtig gestel dat "(w)anneer die Ou Testament dus van Jahwe praat, dan word die Drie-enige God - Vader, Seun en Heilige Gees bedoel. In die sin is Christus by implikasie in die Ou Testament teenwoordig. Hy hoef dus nie in die Ou Testament op gedwonge wyse ingelees te word nie. Om dié rede moet benaderings soos die belofte-vervullingskema, tipologie en allegorie afgewys word". 'n Hervormde teoloog (met 'n "krities-reflektiewe Skrifbeskouing") gaan verder deur te stel dat "(d)ie"Ou Testament verkondig Jesus Christus nie direk nie en ook nie op verborge wyse nie" (Breytenbach, 1987:16). Die Ou Testament is hoogstens oop na die toekoms toe.

Die vraag na die wyse waarop die Christusgetuienis in die Ou Testament voorkom is dus steeds aktueel.

In hierdie artikel word aan die probleem van die Christusgetuienis in die Ou Testament aandag gegee. Die oogmerk is om aan te toon dat die werke van Christus (die Woord, die Seun) as persoon in die Drieheid in die Ou Testament herken kan word, dat sy koms geprofeteer is en dat Hy en sy werke in die Ou-Testamentiese seremonies 
geprefigureer is. Die ondersoek is noodwendig beperk (vir 'n omvangryke ondersoek vergelyk Van Groningen, 1990, met sy 1000 bladsye!), en ter wille van die beperking is gekonsentreer op die tekste wat inherent deel van die drie belydenisskrifte van eenheid van die Gereformeerde Kerke vorm (soos Gen. 1:1, 26; 3:15, 22; Ps. 69:5; Jes. 11:1; 53; Jer. 33:15; Miga 5:1).

Die probleem noodsaak 'n kort uiteensetting van die hermeneutiese vertrekpunte en begripomskrywings wat grondliggend vir die navorsing is. Daarna sal aandag gegee word aan die herkenning van die werk van die Seun as persoon in die Drieheid, die Messiasverwagting en die prefigurasie van Christus in die Ou Testament.

\section{DIE HERMENEUTIESE VERTREKPUNTE}

Die hoofsaak wat God aan die mens wil openbaar, is in die Bybel as die gesagvolle Woord gegee. In hierdie navorsing is die finale teks soos dit in die Ou Testament gegee is, gebruik. Die kennis van God en die verlossing van die mens is duidelik en verstaanbaar gegee, maar sekere perikope, tekste, begrippe en woorde lewer egter in wetenskaplike navorsing probleme op wat alleen deur Skrifvergelyking in die Ou en Nuwe Testament (sui ipsius interpres) tot verheldering gebring kan word. Die waarheid moet ook erken word dat Christus deur sy Gees die verstand van sy dissipels (en die kerk) oop maak om die Skrifte te verstaan (Luk. 14:45).

Metodologies word dus primêr vanuit die gegewe getuienis van die openbaring gewerk terwyl die literêre en historiese komponente sekondèr in ag geneem word. Hierdie openbarings-kognitiewe metode, waar die kenne deur die openbaring bepaal word, rus op drie belangrike vlakke, naamlik op die openbarings-, die historiese en literêre vlakke. Die openbaringsgetuienis is primêr en is nie aan die ander vlakke gelykwaardig nie, maar bepaal die historiese en die literêre insette. Die historiese gedeeltes in die Bybel kan daarom nie ten volle met die metodes van die eksakte geskiedenis ontleed word nie, want God het Hom op 'n besondere en baie keer op 'n wonderbaarlike wyse in die ou en nuwe bedeling geopenbaar - 'n wyse wat nie in die loop van die gewone geskiedenis voorkom nie. Verder is net dié geskiedenis wat vir die openbaring van belang is, meegedeel.

Op literêr-kritiese vlak (bronnekritiek, vormkritiek, struktuurkritiek, semantiek, ens.) het die taalwetenskap pragtige bydraes gelewer (vir 'n oorsig en bespreking vergelyk Armerding (1983) en Hasel (1985)). Vanuit 'n openbarings-kognitiewe benadering is dit egter moeilik om die resultate wat nie met die uniekheid van die gesagvolle geopenbaarde Woord rekening hou nie, te aanvaar. Daar is byvoorbeeld in die Pentateug bronne onderskei wat as volkstradisies of menslike teologieë beskou is (vgl. 
Clements, 1983:30 e.v.). Verder word die feit dat woorde en uitdrukkings meer as een betekenismoontlikheid het, literêr algemeen erken en word die waarde van metafore en beeldspraak selfs hoog aangeprys, maar dat 'n teks in die lig van ander Skrifgetuienis ' $n$ voller betekenis kan hê, word as onkontroleerbare hantering van Skrifgegewens verwerp. 'n Ou-Testamentiese profetiese begrip soos kneg (Jes. 42, 49, 50, 52-53) word meesal op Israel, of 'n Ou-Testamentiese figuur soos 'n profeet of koning betrek, maar uiteindelik nie op die komende Messias nie (naamlik die Christus in die Nivwe Testament) (vgl. Zimmerli, 1967:666-677).

Die skrywers van die Nuwe Testament het as kinders van hulle tyd by die verklaringsmetodes van hulle tydgenote aangesluit. So is dit moontlik om die spore van rabbinistiese verklaringsmetodes in die Nuwe Testament te vind (bv. die twee verbonde in Gal. 4:22-26), maar dit sou verregaande wees om die Nuwe-Testamentiese metodes en die gevolgtrekkings wat verkry is, bloot as rabbinisties te verwerp en daarmee ook die waarheid wat gestel is. As Jesus in Mattheus 22:32 sekere gevolgtrekkings maak, is dit nie dieselfde as rabbinistiese skerpsinnigheid of inlegkunde of allegorese nie maar "die eenvoudige feit (is) net dat Jesus die betekenis van die teks tot sy verste gevolgtrekking voer" (Du Plessis, 1950:154). As die geïnspireerde skrywers in die Nuwe Testament tekste uit die Ou Testament verklaar en op Christus toepas, is hulle woorde openbaringswoorde en gesagvol.

\section{BEGRIPSBEPALING}

Alhoewel albei die begrippe Christos en Messias die "gesalfde" aandui en die Septuagint meesal "salf" en "gesalfde" met chrio en christos vertaal (vgl. Van der Woude, 1974:570), kan die Nuwe-Testamentiese Christus nie sonder meer of volkome met die Ou-Testamentiese messias gelykgestel word nie. Die Ou Testament gebruik die messiasbegrip, op enkele uitsonderings na, met betrekking tot priesters, die profete en veral tot die koningsfiguur. By die konings gaan dit weer veral om die historiese Dawid en sy nageslag (vgl. Hesse, 1974:498 en 502). In die Nuwe Testament word die vervulling van die koninklike messiaanse verwagtings in Jesus Christus gesien, en Christus beskou Homself ook as die Messias (vgl. Grundmann, 1974:527). Die volheid van die messiasbegrip van die Ou Testament kom dus eers in die Christus van die Nuwe Testament tot openbaring.

Naas die koninklike messias, is daar aspekte wat wyer is as die gedagtes rondom die koning en die koninklike heerskappy. Hierdie aspekte het te doen met die besondere werk van die Een wat as die Verlosser, die Middelaar tussen God en die mens, as die Bewerker van die versoening en as God (die Seun) self in die Ou Testament teenwoordig is, en wat in 'n latere tyd duideliker verwag word (vgl. Van Groningen, 1990:20, wat 
ook ander aspekte noem). Ons kry weer 'n skadubeeld van die Een wat in die Nuwe Testament vervul word in die Seun wat die natuur van die mens aangeneem het.

In bogenoemde engere en ruimere sin wil ons van die Christus in die Ou Testament praat. Christus word nie direk genoem nie, maar die aangewese, met krag begiftigde, gesagdraende Christus, is indirek maar tog wesenlik teenwoordig, of sy koms word afgeskadu of belowe. Dit moet dié Christus wees waarvan die Ou Testament getuig (Joh. 5:39 en Luk. 24:27, 44; vgl. Greijdanus, 1955:297).

\section{DIE WERK VAN DIE SEUN AS PERSOON IN DIE DRIE-EENHEID}

In die Nuwe Testament vind ons 'n duidelike getuienis van die Drie-eenheid (Matt. 3:16,17; 28:19; Luk. 1:35; 2 Kor 13:13 en 1 Joh. 5:7,8. Vgl. NGB, art. 9 en HK vr. 25). Die Godsopenbaring het net een sentrale boodskap: God die Vader, die Seun en die Heilige Gees (vgl. De Groot, 1953:9-10). Daar is inderdaad 'n besondere beklemtoning van die werk van Christus, maar Christus word nooit van die Vader en die Heilige Gees losgemaak nie. In 'n sekere sin het die Seun wel 'n besondere plek: tog is dit altyd Christus, die ewige Logos, een met die Vader en die Heilige Gees (vgl. Lion-Cachet, 1985:34; Edelkoort, 1941:10-11). Ons het dus te doen met 'n Teosentriese boodskap wat 'n Christologiese toespitsing het (vgl. Floor, 1979:59). Hier kan ook verwys word na die algemene belydenisskrifte waarin die kerke die drie-enige God sentraal stel: "Elkeen wat wil salig word, vir hom is voor alle dinge nodig dat hy die algemene geloof moet hou ... Dat ons die enige God in die Drieheid en die Drieheid in die Eenheid eer ..." (Athanasius). Hieruit blyk dit dat Hoekstra se gedagte van twee sentrums van die Bybel (1926:166-167), naamlik 'n Christosentriese en 'n Teosentriese, verwerp moet word.

In die Ou Testament openbaar God Hom ook as die drie-enige God. God is EEN (Deut. 6:4). As bewys van die Drieheid verwys die NGB, art. 9 na die meervoudsvorm in Genesis 1:26,27 en 3:22. Die verklaring van "laat Ons mense maak na ons beeld ..." het deur die eeue heen probleme veroorsaak. Verskillende moontlikhede is genoem: die HERE praat in 'n hemelse hof (met die engele), of die skrywer dink nog aan 'n politeïsme, of ons het met 'n pluralis majestatis te doen, of ons moet in hierdie woorde 'n selfaansporing hoor, of dit is ' $n$ vorm van selfberaadslaging, of ons moet ' $n$ pluraliteit in die Goddelike wese veronderstel (vir 'n opsomming van die verskillende sienings vgl. Wenham, 1987:27-28, of Gispen, 1974:70-73). Calvyn se siening is dat God met Homself beraadslaag (1970:43) terwyl Skinner, Von Rad, Zimmerli, Kline, Mettinger, Day, Gispen en Wenham aan 'n beraadslaging in ' $n$ hemelse hof dink (vgl. Wenham, 1987:27 en 28). Hoe die meervoudsvorm ook al in sy onmiddellike konteks verstaan is, sluit egter nie uit dat die meervoudsvorm in die breër openbaringskonteks 
verwys na 'n pluraliteit soos dit in die Nuwe Testament geleer word nie. In die meervoudsvorm kan ons die spore van die Drieheid verstaan (vgl. Van Selms, 1967:36). Die meervoudsvorm dwing ons om aan 'n pluraliteit te dink en die Christene het in die lig van die ganse Skrif nie gedwaal om aan die Drie-eenheid te dink nie (vgl. Gispen: 1974:73).

Die Ou Testament benoem Hom ook as die Skeppper (Gen. 1 en 2; Eks. 20:11), die onderhouer (Spr. 16:13; Jer. 23:23-24), die Een wat gesagvol spreek (Jes. 44:6; 44:24; 45:1; Jer. 14:1; 15:1; 16:1; Eseg. 28:1), die Koning (Ps. 2:6; 10:16; 24:7-8; 68:25

$\left(\mathrm{MT}^{1}: 24\right)$ ) en die Verlosser (Ps. 19:5; Jes. 41:14; 44:14; 49:7). Verder word die werking van sy Gees genoem (Ps. 51:13; 139:7; Jes. 59:21; 61:1; Eseg. 36:27). Ons kan uit bogenoemde tekste reeds die werke van die Drie-eenheid erken.

By die lees van die Ou Testament kan die werk van die persoon van die Seun (die Woord) wat sekerlik meer is as sy konings- of verlossingswerk, herken word (kyk na Luk. 24:25-27, 44 en Joh. 5:39 en vgl. ook Tasker, 1972:89; Godet, 1914:447.) Hy word as die Seun in die een Goddelike wese herken. Net so word die Vader (vgl. Jes. 44:8 (MT: 8)) en die Gees herken maar dit is seker anders as wat die Ou-Testamentiese gelowige van dié persone kennis geneem het. Die Seun word in die Drieheid herken, maar om Hom te identifiseer en op 'n Nuwe-Testamentiese wyse Jesus Christus te noem, misken die gang van die openbaringsgeskiedenis.

'n Woord oor die Engel van die HERE is hier gepas. In die historiese gedeeltes is sprake van die Engel van die HERE of van God. (Gen. 16:9; 22:11; Rigt. 6:11; 2 Kon. 1:3, 15). (Die Engel van die HERE kom 58 keer voor en die engel van God 11 keer.) In die meeste gevalle is die Engel van die HERE die verlosser of die leier wat die redding bring of die aankondiger van 'n goeie boodskap. Hy is ook die bewaarder. In enkele gevalle bring Hy egter die oordeel en verwoesting (2 Sam. 24:16 e.v.; 1 Kron. 21:15 e.v.; Ps. 35:5,6). Wie die Engel is, word verskillend verklaar: Hy is die Woord; 'n besonder boodskapper maar tog 'n geskape wese; 'n verskyningvorm van die HERE self of 'n gestalte wat die HERE net afbeeld. Andere dink aan 'n latere invoeging van 'n redakteur wat die HERE tog in gedagte gehad het (vgl. Ficker, 1971:907). Uit bostaande blyk dat Hy Goddelike eienskappe het en dat $\mathrm{Hy}$ 'n verskyningsvorm of 'n besondere gesant van die HERE is. Daar is egter nie genoegsaam getuienis om Hom sonder meer as een van die persone van die Drieheid te identifiseer nie (vgl. Van Groningen, 1990:218).

\footnotetext{
${ }^{1} \mathrm{MT}=$ Masoretiese teks
} 


\section{DIE OU-TESTAMENTIESE MESSIASVERWAGTING}

Die Ou-Testamentiese volk het 'n messiaskoning verwag. Plek-plek styg die messiasverwagting egter uit bo die verwagting na 'n gewoon-menslike koning. Vanuit 'n Nuwe-Testamentiese perspektief sou ons van 'n Christusverwagting kon praat. Edelkoort (1941:7) skrywe dan ook: "Het Oude Testament bevat Messiasverwachting, inderdaad; maar het bevat veel meer dan dat alleen, het vertolkt ook de verwagting van een heilsbrenger, een redder, een wereldheiland, ja zelfs van een Knecht des HEEREN, die door zijn lijden menschen ten zegen zou zijn. Het is dit meerdere, dat in de aanduiding 'Messiasverwachting' niet ten volle tot uitdrukking zou zijn gekomen, en dat met het woord 'Christusverwachting' wel zijn genoemd." In 'n Ou-Testamentiese konteks pas dit egter om van Messiasverwagting te praat omdat die volheid van die Messiasbegrip eers in die Christus van die Nuwe Testament vervul word.

Die verwagting word moontlik al in die "tuingeskiedenis" gewek in die aankondiging van die stryd tussen die saad van die slang en die saad van die vrou (vgl. Gen. 3:15 soos ook aangehaal in NGB, art. 17. Vgl. ook HK vr. 19). Die verklaring van die sogenaamde "proto-evangelie" (Gen. 3:15) wentel allereers om die aard van die verhaal. As hierdie gedeelte bloot as 'n storie (of saga) beskou word, is dit maklik om te sê dat ons met 'n etiologie te doen het: "Why men try to kill snakes, and why snakes try to bite men" (vgl. Wenham, 1987:80; Simpson, 1952:508; Von Rad, 1963:89; Fouché, 1988:57). Word die verhaal ernstiger opgeneem, gaan dit eerstens om die betekenis van die woord sjûf (vergruis, byt, met kwade bedoelings na iets neig). In die Afrikaanse vertalings word die woord een keer met "vermorsel" en dan weer met "byt" vertaal: "Hy sal jou die kop vermorsel, en jy sal hom in die hakskeen byt" (Gen. 3:15). Die vraag is dan of daar ' $n$ oorwinnaar in die stryd tussen die saad van die vrou en die van die slang sal wees. Dat die kop van die slang vermorsel sal word, staan in skerp teenstelling met hakskeenbyl/vermorseling wat die saad van die vrou sal ondergaan. Die kopvermorseling dui op 'n oorwinning oor die slang (vgl. Gispen, 1974:146). Vervolgens is "saad" kollektief en die hele nakomelingskap word bedoel. Dit is ook grammaties normaal om van die kollektiewe nakomelinge in die enkelvoud te skrywe. Calvyn (1970:107-109) dink daarom eerstens aan die stryd tussen die menslike geslag en die slange. Dan gaan dit om die stryd tussen die kerk, die gelowiges en Satan met sy trawante. Die Here sal die uiteindelike oorwinning oor die Satan behaal (Rom. 16:20). Ons kan hier egter verder as Calvyn gaan en in besonder met Christus se werk as hoof van sy kerk rekening hou (vgl. Verhoef, 1990:114).

In die Nuwe Testament vind ons geen duidelike aanhaling of verklaring van hierdie teks nie. Tog kan ons in die lig van die Nuwe-Testamentiese openbaring wat Christus 
se oorwinning oor die aartsverleier bevestig (vgl. Rom. 16:20; Hebr. 2:14 en Open. 12:9 en Gal. 3:16), Genesis 3:15 wel in wyer sin op die komende Christus betrek (vgl. Van Groningen, 1990:113; Kidner, 1968:70). Die Jode het al voor Christus hierdie teks as 'n heenwysing na die Messias beskou en die kerkvaders het dit vanaf Justinus (ongeveer 160 A.D.) as die proto-evangelie beskou (Wenham, 1987:80-81).

Die bevel van die HERE aan Abram om uit Haran weg te trek, het die verwagting op 'n land, 'n nasie en 'n persoonlike identiteit gewek (Gen. 12:1-3). Israel het na die uittog verwag om 'n koninkryk van priesters en 'n heilige nasie te word (Eks. 19:6). Die volk het in Palestina begin lewe uit die verwagting van 'n ewige Dawidiese koningskap (2 Sam. 7:12-13) en daarmee saam dat die puinhope van die koningshuis en die koningsvolk weer opgebou sal word (Amos 9:11). Die belofte van 'n kind (vgl. Jes. 9:16, die enigste plek waar die 1983-Afrikaanse Vertaling by 'n messiaanse teks 'n hoofletter gebruik) wat gebore sou word, spreek eerstens van 'n natuurlike koningskind (Kaiser, 1972:128), maar die Kind sal ook Goddelike eienskappe dra en wys in 'n enger en ruimer sin na die Messias (vgl. Van Groningen, 1990:538, 553; Calvijn, 1985:268).

Hierdie verwagting is seker meer as 'n opportunistiese lewensiening (soos Goldingay (1981:122) dit formuleer: "It ever calls people to look at die future in the light of the past, so as to see how to live in the present"), want dit is gegrond op die profetiese woord van God aan die mens (vgl. Jes. 40:1-2). Baie mense het vanuit hierdie verwagting gelewe (Luk. 2:25; Mark. 15:43).

Die Ou Testament bevat ook profetiese verwysings na 'n lydende verlossingsfiguur. Dink maar aan die bekende knegliedere (Jes. 42:1-9, 49:1-7, 50:4-11, 52:13-53:12) of aan sekere smeekliedere van Dawid soos byvoorbeeld Ps. 22, 35 en 69. Jesaja 53:5,7,9 en Psalm 69:5 word in die NGB, artikel 21 aangehaal (vgl. HK vr. 37). Ons laat die vrae rondom die plek (of hulle ' $n$ integrale deel van Jes. 40-55 is, of eers apart bestaan het), of die aard (of hulle werklik liedere is) van die knegliedere onaangeroer (vgl. Knight, 1984:3; Westermann, 1969:92). 'n Volledige bespreking van al die moontlike verklarings oor die identiteit van die kneg word ook nie beoog nie (vgl. Van Groningen, 1990:574 e.v.). Dit is wel duidelik dat die kneg soms kollektief en dan weer as 'n individu verstaan moet word. Soms is die kneg net 'n stem, dan is hy Jesaja of 'n ander profeet, of 'n individu wat nie uit Ou-Testamentiese gegewens herken kan word nie, of miskien Kores, of die kollektiewe Israel, of die res uit Israel. Westermann (1969:93) sê dat ons nie die vraag moet beklemtoon nie: "The veiled manner of speaking is intentional." Die kneg word nooit messias genoem nie, maar Kores wel! Van Groningen (1990:612) stel dit so: "The Servant is not referred to as mâsjiach, but 
he has all the characteristics and responsibilities ascribed to the Messiah throughout the Old Testament." Die Nuwe Testament is vol aanhalings en verwysings na die knegliedere (vgl. Aland, 1968:911-912 wat meer as 60 aanhalings en verwysings aantoon), terwyl Christus in sy lyding nie beter beskrywe kon word as in die woorde van Jesaja 52:13-53:12 nie. Calvyn, Ridderbos, Allis, Delitzch, Banks, Young en Van Groningen verklaar elkeen op sy eie manier die lydende Kneg in Jesaja 52-53 as 'n profetiese heenwysing na die Christus (vgl. Van Groningen, 1990:646). Westermann (1969:257) maak die opmerking: "... there is point for point correspondence with the Church's confession as it is given in the Apostle's Creed - born, suffered, died and was buried. The similarity in structure (the Creed, too, is the confession of men who had been given salvation) is far more important than quotations from Isa. $52 \mathrm{f}$. here and there in the New Testament". Sy laaste sin kan betwyfel word omdat die Belydenis juis op die getuienis van die Nuwe Testament rus.

In Psalm 69 (direk aangehaal in art. 21, NGB), wat naas Psalm 22, die mees aangehaalde psalm in die Nuwe Testament is, hoor ons die gesmeek van een in onvergelykbare menslike lyding. Dit is egter meer as net 'n verwoording van lyding oor die algemeen (soos Weiser, 1962:493, dit beskou). Ons het hier, soos in Jesaja 52-53, 'n profetiese prefigurasie van die lyding van Christus (vgl. Kidner, 1973:245). "The whole Psalm is typically prophetic, in as far as it is a declaration of a history of life and suffering moulded by God into a factual prediction concerning Jesus the Christ ... " (Delitzsch, 1949:278).

Die kernvraag is egter of God in die Ou Testament 'n Messiasverwagting geskep het waarin Hy in die profetiese woord (en die geskiedenisgebeure) die koms van Christus en die nuwe bedeling bedoel het. Ons kan aanvaar dat die profete en die volk van die ou bedeling Christus nie by name geken het of die omvang van die nuwe bedeling begryp het nie. Die volle betekenis van die profesieë en die seremonies sou eers later bekend geword het. A Fernàndez (vgl. Goldingay 1981:108) praat van "the deeper meaning, intended by God but not clearly intended by die human author, that is seen to exist in die words of Scripture when they are studied in the light of further revelation or of development in the understanding of revelation". Ons verkies om nie van 'n dieper betekenis te praat nie omdat dit die indruk kan wek dat die woorde van die profesieë twee betekenisse het. Die profesieë het maar een betekenis, maar die volle implikasie van die woorde is nie terstond duidelik nie. Dit is soos dié woorde van Christus wat die dissipels eers na sy opstanding en verheerliking onthou en ten volle verstaan het (Joh. 2:22; 12:16). Jesus het van die vrou wat sy hoof gesalf het gesê: "Sy het vooruit al my liggaam vir die begrafnis gesalf" (Mark. 14:8). Hierdie woorde heteken nie dat sy ten volle van sy begrafnis bewus was en doelbewus om hierdie rede 
sy hoof gesalf het nie. Sy wou Hom heel waarskynlik as Messias eer (vgl. Van Leeuwen, 1951:177) maar God het die daad besonderlik op Christus se begrafnis betrek. Die mense in die Ou Testament het ook gedagtes uitgespreek en op skrif gestel waarvan hulle self nie die volle draagwydte besef het nie.

Die vraag of God in die Ou-Testamentiese Messiasverwagting 'n Christusverwagting gewek het, kan eers bevestigend beantwoord word as die Nuwe Testament meerdere lig daarop werp of as die Ou-Testamentiese beloftes tot vervulling gekom het. In die beskrywing van die verhouding Ou tot Nuwe Testament is die voorstelling beloftevervulling 'n halwe waarheid (vgl. Helberg, 1983:100). Die Ou Testament gee nie bloot beloftes wat in die Nuwe Testament in vervulling kom nie. God openbaar Hom reeds in die Ou Testament as die Skepper, Koning, Regter, Verlosser en Trooster (om maar 'n paar te noem). Die Ou Testament het as openbaring 'n eie reg en 'n verklaarder kan God eers ten volle leer ken as hy die Ou Testament in sy eie konteks en dan in vergelyking met die Nuwe Testament verklaar het.

Die Ou Testament wek ook verwagtings wat in die ou bedeling vervul is, maar ook dié wat nog op vervulling wag. Daar is inderdaad ook 'n belofte-vervullingsaspek. Dit is die moeite werd om nader op die begrip vervul, soos dit in die Nuwe Testament gebruik word, in te gaan.

Die woord verul ( $\pi \lambda$ nów) word heel konkreet gebruik om aan te dui dat 'n houer wat leeg of gedeeltelik gevul is, volgemaak word (vgl. Matt. 13:48; Hand. 2:2; 5:3). In geestelike sin word dit gebruik om aan te dui dat aan ' $n$ bevel of 'n eis voldoen word (Rom. 13:8). In dié sin het Christus ook gekom om die wet en die profete te vervu! (Matt. 5:17). "His task is to actualise the will of God made known in the OT ... He has come in order that the full measure appointed by God Himself may be reached in Him. His work is an act of obedience also and specifically in the fact that He fulfils God's promise, cf. Mt 3:15" (Delling, 1968:284). Die woord het 'n nog groter eis tot vervulling as op die eskatologiese element daarin gelet word (vgl. Matt. 8:17 en 12:17). Wat in die Ou Testament belowe word, moet $(\delta \in \tilde{\imath})$ vervul word. Dit is 'n heilige "moet": "Dit is die woorde wat ek met julle gespreek het toe Ek nog by julle was, dat alles wat oor My geskrywe is in die wet van Moses en die profete en die psalms, vervul moet word" (Luk. 24:44).

Gunneweg (1978:30) oordeel dat die verlossingselement van die kruis en die opstanding desondanks alles nie uit die Ou Testament bewys kan word nie. So wil Johannes die aanstoot van die kruis alleen met gegewens uit die Ou Testament verduidelik en 
aanvaarbaar maak (vgl. Joh. 1:45 e.v.; 7:42 en 52). Maar alle verwysings na die Ou Testament kan nie bloot as voorbeelde gesien word nie. Inteendeel, die belofteelement rondom die Messiasverwagting is in die Ou Testament so sterk dat Paulus dit uit 'n apologetiese oorweging gebruik. Die aanhalings in sy brief aan die Galasieërs dien as bewysvoering teen sy Joods-Christelike teenstanders in sy stryd oor die betekenis van die wet en die besnydenis (vgl. Floor, 1979:61). Die Ou-Testamentiese Messiasverwagting kan vanuit die Nuwe Testament net nie geïgnoreer of ontken word nie. "Want hoeveel beloftes van God daar ook mag wees, in Hom is hulle ja en in Hom amen, ..." (2 Kor. 1:20).

In Psalm 110:1 sê Dawid: "Die HERE het tot my Here gespreek." 'n Profetiese boodskappersformule word gebruik naamlik "die HERE spreek" (vgl. 2 Sam. 23:1-7). In Mattheus 22:41-46 (vgl. ook Hebr. 1:13) word hierdie woorde direk op Christus betrek. Kyk ook na Psalm 110:4 "die orde van Melgisédek" en na Hebreêrs 5:6; 7:17 (of breër in 6:19-7:28). Alhoewel ons hier eerstens met 'n koningspsalm te doen het, en daar sekerlik grond is om "my heer" in 110:1 met "koning" te vertaal soos dit in die 1983-Afrikaanse Vertaling gedoen is, sou dit kortsigtig wees om hierdie psalm net as 'n lied oor 'n aardse koning te beskou. Vir die Nuwe-Testamentiese Kerk is die prefigurasie van die Messias deel van die verklaring van dié psalm. Ons kan selfs verder gaan en sê dat God die voller betekenis as 'n heenwysing na die Christus bedoel het.

Ons sou egter te ver gaan as ons sou aanvaar dat alle beloftes soos hulle in die $\mathrm{Ou}$ Testament gegee is, woordeliks in vervulling gegaan het of dat hulle nog op ' $n$ letterlike vervulling wag. Baie van die Ou-Testamentiese beloftes is nog nie vervul nie (Jer. 31:34) en sommige profesiee is in die taal en die konteks van die hoorders uitgespreek (vgl. Eseg. 40-48). Ons sal seker daarmee moet rekening hou dat die vervulling anders plaasgevind het en sal plaasvind as wat ons oppervlakkig in gedagte het. Hoe sal Jesaja 11:7-8 (o.a. die suigeling wat by die gat van 'n adder speel) vervul word?

'n Laaste aspek in dié verband. Die Nuwe-Testamentiese geslagsregisters bind Christus, na sy menslike natuur, aan die messiaanse Dawidiese geslag. In die Nuwe Testament kom veral retrogressiewe geslagsregisters voor wat Christus se "bloed"-band van Josef via Dawid, aan wie se dinastie die belofte van die ewige koningskap gegee is (2 Sam. 7:16), aantoon. Abraham het die belofte ontvang dat in hom al die geslagte van die aarde geseën sal word (Gen. 12:3) en die beloftes word in 'n verbond aan hom bevestig waarin ook gestel word dat konings uit hom sal voorkom (Gen. 17:6). In die NGB, artikel 18 word na Jesaja 11:1 en Jeremia 33:15 verwys om die natuurlike band van Christus met die verwagte Messias te verantwoord. Christus is die takkie uit die stomp van Isai en die verwagte Dawid, die Spruit van geregtigheid (vgl. Calvijn, 
1983:91, Harrison, 1973:144. Bright, 1965:296, en Laetsch, 1965:269, verstaan die spruit-begrip meer kollektief).

In Lukas word Christus se geslagsregister deurgetrek tot by Adam, aan wie die HERE belowe het dat sy saad die kop van die slang sal vermorsel (Gen. 3:15). Lukas (en in 'n sekere sin ook Johannes) het egter nog verder teruggegaan deur te stel dat Adam die seun van God is. Johannes (Joh. 1:1) gee die volledige openbaring deur te skrywe: "Die Woord was by God, en die Woord was God." Die NGB, artikel 10 haal Miga 5:1 aan om die ewige bestaan van Christus te bevestig. ' $n$ Vors sal uit Betlehem uitgaan, maar Betlehem is klein onder die geslagte van Juda. Dit gaan daarom nie soseer om die plek nie, maar om die geslag (Ridderbos, 1949:91). Hier is sprake van die takkie uit die geslag van Isai (Jes 11:1), en: "(s)y uitgange is uit die voortyd, uit die dae van die ewigheid". "Ewigheid" ('ôlam) kan verste tyd, vergange tyd, maar ook onbegrensde en onoorsienbare tyd, dit wil sê ewigheid beteken. Die betekenis kan alleen uit die konteks vasgestel word. In Miga is dit nie so duidelik nie (Jenni, 1976:230,232). Uit die openbaringskonteks kan hier tog aan "ewigheid" gedink word (vgl. Keil \& Delitzch, 1949:480-481; Van Groningen, 1990:503).

Samevattend: daar is in die Ou Testament 'n (Messias)verwagting wat in die beloftes verseël en in die Nuwe Testament in Christus vervul word, maar daarmee word nog nie beweer dat elke Ou-Testamentiese teks in die belofte-vervullingsraamwerk moet inpas en as 'n belofte verklaar moet word nie.

Die Ou Testament skep dus die verwagting (1 Petr. 1:10-12) en gee die beloftes van 'n komende Messias wat in die Nuwe Testament in Christus hulle vervulling vind (Matt. 5:17; 8:17; 27:9; Luk 24:44; en vergelyk ook H.K. vr. en antw. 19).

Die pogings om Christus simplisties in 'n belofte-vervulling skema in te forseer, moet verwerp word.

\section{DIE PREFIGURERING VAN CHRISTUS}

In die Nuwe Testament is daar verwysings na die Ou Testament wat nie direk aan OuTestamentiese beloftes gekoppel kan word nie maar verband hou met seremonies, gebeurtenisse en persone of persoonlikheidstrekke wat in die Ou-Testamentiese openbaringsgeskiedenis voorkom (vgl. Hebr. 10:19-22 en Lev. 16; 1 Kor. 10:4 en Eks. 17:6 of Num. 20:7-11; 1 Petr. 3:20-21 en Gen. 6-7; Rom. 5:14 en Gen. 2:7 en Gen. 3; 
Matt. 27:9 en Sag. 11:12; Matt. 13:35 en Ps. 78:2).

Die vraag is of God hierdie seremonies, gebeurtenisse of persone in die Ou Testament as voorbeelde van gebeure in die tyd van Christus of as tipes van Christus bedoel het. Het dit ook "profetiese krag" ingehou of het die Nuwe-Testamentiese skrywers die OuTestamentiese gebeurtenisse en persone net as voorbeelde of illustrasies ter verduideliking van die optrede van Christus gebruik? Het ons hier met tipologie te doen waar die tipe ' $n$ aspek van 'n gebeurtenis of ' $n$ persoon is wat as 'n voorbeeld, analogie of profetiese afbeelding van ' $n$ latere gebeurtenis of persoon beskou word? Of het ons met allegoriee te doen wat alle aspekte van 'n verhaal geestelik, metafories of fiktief verklaar (vgl. Pred. 12:1-6)?

Die Nuwe-Testamentiese skrywers het die verklarende taal van hulle tyd gebruik. Vergelyk Rom. 5:14 "Adam ..., wat 'n voorbeeld ( túmos) is van Hom wat sou kom"; Hebr. 8:5 "... hulle wat 'n afbeeldsel (ن̛⿱óó dinge bedien"; Hebr 9:9 "Dit was 'n beeld (ropaßoגń) met die oog op die teenwoordige tyd ...". Tog is hierdie taalgebruik en die verklaringsmetodes wat die NuweTestamentiese skrywers gebruik het, nie onbetroubaar nie. So was Paulus se prediking geinspireerde prediking en dit lei daartoe dat sy vertolking van die Ou Testament nie die vrug was van tydsgebonde eksegese nie, maar dit was gegrond op die geloofsbeslissing en geloof in die selfopenbaring van Jesus Christus self (vgl. Floor, 1979:57). Paulus het dus desondanks sy metode tot die oortuiging gekom dat God in die OuTestamentiese gebeure en persone, tipes van Christus en sy optrede gegee het. "Sonder om te moraliseer of te allegoriseer sal ons uit die Ou Testament aan die gemeente verduidelik dat Christus, die Seun van God, sy eie koms in die vlees geprefigureer, afgebeeld het in die geskiedenis van die volk Israel, in die seremonies van die wet, in die lyde van die reguerdiges en in die stem van die profete" (Floor, 1981:63).

Hiermee word geen ongekontroleerde afbeeldende of tipologiese verklaring bepleit nie. Die kritiek teen 'n prefiguratiewe of tipologiese verklaring van die Ou Testament waarin Christus in elke teks ingelees word en waar die selfstandige openbaring wat God in die Ou Testament gegee het, verbygegaan word, is geregverdig. Hierdie soort van verklaring kan tot 'n subjektiewe en willekeurige verklaring aanleiding gee. Alhoewel sommige navorsers die moontlikhede van 'n wetenskaplike kontrole ontken (vgl. Gunneweg, 1978:212), is daar in die Nuwe Testament wel kontrole moontlik op grond van die openbaring in die Skrif en veral ten opsigte van Christus. Dieselfde God wat Hom in Christus openbaar het, het Hom ook in vooruitsig gestel in die geskiedenis van die verbondsvolk in die ou bedeling. 
Ons kan alleen op grond van die getuienis van die Nuwe Testament aanvaar dat God Christus reeds afgebeeld het in die geskiedenis, die seremonies en in sekere persone van die ou bedeling. Die afbeelding of tipe is egter so in die Ou-Testamentiese openbaring ingebed dat dit nie daaruit losgeskeur kan word sonder om die volle betekenis van die openbaring te skaad nie.

Sekere persone of gebeurtenisse in die Ou Testament word op tradisionele wyse tipologies verklaar. Jona wat drie dae in die ingewande van 'n vis was, is tipe van Christus se verblyf in die graf (vgl. Matt. 12:39-41; Luk. 11:29-30). Dit is egter opvallend dat Ou-Testamentiese persoonlikhede selde en dan ook net ten opsigte van 'n bepaalde aspek as ' $n$ tipe van Christus in die Nuwe Testament beskryf word. Christus is koning volgens die orde van Melgisedek (Ps.110:4; Hebr. 5:6-11); Hy is die tweede Adam (1 Kor. 15:45); sy bloed is beter as die bloed van Abel (Hebr. 12:24) en Hy is die een soos Moses (vgl. Deut. 18:15 met Joh. 1:46). In die meeste van die gevalle kan by die sogenaamde tipes 'n groot vraagteken geplaas word of kan dié tipes heeltemal verwerp word. Om Josua (op grond van sy naam) of die "vrederyk" van Salomo (Christus se vrederyk) tipologies op Christus en sy ryk te betrek, het geen Nuwe-Testamentiese grond nie.

Die Ou-Testamentiese kultus gee in die hoëpriester (vgl. Hebr. 9:7-15), die offers (vgl. Hebr. 9:3-14; 10:1-10) en die paaslam (vgl. 1 Kor. 5:7) 'n prefigurasie van Christus. Daar word veral in Hebreërs (vgl. hoofstukke 8 en 9) na die tabernakel verwys. Childs (1974:544) merk op dat die skrywer van Hebreërs wil aantoon dat "the Old Testament picture of the tabernacle is a testimony to Jesus Christ, whether in its fulfillment or its abrogation through a more perfect form". Die verklaring van die kultiese seremonies en Ou-Testamentiese heiligdomme verg egter groot versigtigheid. In Johannes 3:14-15 word Christus wel met die kultiese seremonie van die koperslang (Num. 21:9) vergelyk, maar Christus word nie direk met die bok vir Asasel (Lev. 16:7-10) verbind nie. Vischer (1946:277) skrywe oor Numeri 4: "In der Tat enthält dieses Kapitel einen merkwärdigen Hinweis auf den Christus Jesus." Op allegoriese wyse probeer hy dan om die koei wat buite die laer gebring en daar gedood is, met Christus te vergelyk. So word die simboliek van die seremonie egter op subjektiewe wyse tot die absurde oorspan.

Samevattend kan gestel word: sekere afbeeldings en tipes van Christus en die Christusgebeure kan op grond van die Nuwe-Testamentiese getuienis (bv. Rom. 5:14; Hebr. $8: 5 ; 9: 9)$ in die Ou Testament aangetoon word. Ons kan van 'n prefigurasie in die geskiedenis praat, maar 'n gedwonge of subjektiewe tipologiese verklaring van Skrifge- 
deeltes of tekste moet verwerp word.

\section{KONKLUSIE}

- Die wyse waarop die Christusgetuienis in die Ou Testament verstaan word, hang ten nouste saam met die uitgangspunt en die metodologie van die navorser. Die erkenning dat die Woord aan eenvoudige mense gegee is sodat hulle dit maklik kan verstaan, en dat die teologiese wetenskap in sy verklaring by hierdie helderheid (die perspicuitas sacra Scriptura) moet aansluit, lei daartoe om die getuienis van die Nuwe Testament ernstig te neem.

- Die erkenning dat die eksplisiete en implisiete waarheid van die openbaring in die Ou Testament alleen bepaal word deur vergelyking van die Skrif in sy geheel (die interskriftuurlike getuienis), lei daartoe dat 'n navorser byvoorbeeld die woorde van Christus dat Moses, die profete en al die Skrifte/Psalms van Hom getuig (Luk. 24:27, 44; Joh. 5:39), in die verklaring van die Ou Testament moet navors en bepaal. "Hij (FN - Jesus) had er (FN - het Oude Testament) zoozeer zijn eigen persoon in aanschouwd, dat het hem onmogelijk scheen, dit boek ernstig bestudeerd te hebben en niet onmiddellijk tot hem te komen" (Godet, 1914:447). Dit is tog jammer dat die 1983-Afrikaanse Vertaling nie meer hoofletters gebruik het om die "Messiaanse" tekste aan te dui nie.

- Alhoewel die persone van die Drie-eenheid nie in die Ou Testament helder onderskei word nie, is dit moontlik om die persoon van die Seun te herken op grond van sy werke, soos dit in die Nuwe Testament beskrywe word.

- Die Ou Testament wek ' $n$ Messiasverwagting en gee beloftes wat alleen in Christus vervul kan word.

- In die Ou Testament word Christus in sekere seremonies, gebeurtenisse en persone afgebeeld of geprefigureer. Hierdie prefigurasie kan in die lig van duidelike Nuwe-Testamentiese gegewens aangetoon word. Alle subjektiewe of selfs tradisionele tipes wat nie in die Nuwe Testament as sodanig bevestig kan word nie, moet afgewys word.

- Die algemene en die besondere belydenisgeskrifte van eenheid in die Gereformeerde Kerke kan steeds op grond van die Ou en Nuwe Testament as 'n betroubare voorveronderstelling en riglyn vir die verstaan van die Christus in die Ou Testament geneem word. 


\section{BIBIOGRAFIE}

ALAND, K. red. 1968. The Greek New Testament (UBS). Stuttgart: Württemberg Bible Society. ARMERDING, C.E. 1983. The Old Testament and criticism. Grand Rapids : Ecrdmans. BOUMA, C. 1950. Het evangelie naar Johannes. Vol. l. Kampen : Kok.

BREYTENBACH, A.P.B. 1987. Die vraag na die teenwoordigheid van Jesus Christus in dic Ou Testament. Die Henomer, 79(3):16 Junie.

BRIGHT, J. 1965. Jeremiah. New York: Doubleday.

'ALVIJN. J. 1970. Genesis. Vol. I. Kampen : De Groot.

CALVIJN, J. 1983. Verklaring van de Bijbel. De profeet Jeremia. Vol. III. Kampen : De Groot.

CALVUN, J. 1985. Verklaring van de Bijbel. De profect Jesaja. Vol. I. Kampen : De Groot.

CHILDS, B.S. 1974. Exodus (OTL). London : SCM.

CLEMENTS, R.E. (1976) $1983^{3}$. A century of Old Testament study. Guildford : Lutterworth.

DE GROOT, J. 1953. Macht en wil. Nijkerk : Callenbach.

DELITZSCH, Franz. 1949. Biblical commentary on the Psalms. Tr. Bolton, F. Grand Rapids : Eerdmans.

DELLING, G. 1968. plêrês. (In Kittel, G., red. TDNT. Vol. I. Grand Rapids : Ecrdmans.)

DU PLESSIS, S.J. 1950. Jesus en die kanon van die Ou Testament. Potchefstroom : Wever.

EDELKOORT, A. H. 1941. De Christusverwagting in het Oude Testament. Wageningen : Vecnman.

FLOOR, L. 1979. Eksegese en prediking by Paulus. (In Van't Spijker, W. red. Uw Knecht Hoort. Amsterdam : Bollard, p. 53-63.)

FICKER, R. 1971. mal'ak, Bote. (In Jenni, E., red. THAT, Vol. I Munchen : Kaiser Verlag.)

FOUCHé, H.L. 1988. Genesis 2 en 3. (In Burger, C.W., red. Riglyne vir dic prediking oor die Genesisverhale. Kaapstad : NG Kerk, p. 19-120.)

GISPEN, W.H. 1974. Genesis. Kampen : Kok. -

GODET, F. 1914. Kommentaar op het evangelie van Johannes. Utrecht : Kemink \& Zoon.

GOLDINGAY, J. 1981. Approaches to Old Testament interpretation. Leicester : Interv. Press.

GRELJDANUS, S. 1955. Lucas. Vol. I. Kampen : Kok.

GRUNDMANN, W. 1974. chrio kll. (In: Kittel, G., red. TDNT. Vol. 9. Grand Rapids : Ecrdmans.)

GUNNEWEG, A.H.J. 1978. Understanding the Old Testament. London : SCM.

HARRISON, R.K. 1973. Jeremiah and Lamentations. London : Tyndale.

HASEL, G.F. 1985. Biblical interpretation today. Lincoln, Nebraska : College View Printers.

HELBERG, J.L.. 1983. Verklaring en prediking van die Ou Testament. Potchefstroom : PTP.

HESSE, F. 1974. chrio kil. (In: Kittel, G., red. TDNT. Vol. 9. Grand Rapids : Eerdmans.)

HOEKSTRA, T. 1926. Gereformeerde Homiletiek. Wageningen : Zomer \& Keuning.

JENNI, E. 1976. 'olam Ewigkeit. (In Jenni, E., red. THAT, Vol. I München: Kaiser Verlag.)

KAISER, O. 1972. Isaiah (OId Testament library). London : SCM.

KEIL, C.F. \& DELITZCH, F. 1949. The Pentateuch. Vol. II. (BCOT). Tr. Martin, J. Grand Rapids Eerdmans.

KIDNER, D. 1\%8. Genesis. London : Tyndale.

KIDNER, D. 1973. Psalms 1-72. London : Inter-varsity.

KNIGHT, GA.F. 1984. Isaiah. Servant theology. Edinburgh: Handel.

LAETSCH, T. 1965. Bible commentary. Jeremiah. Saint Louis : Concordia.

LION-CACHET, F. N. 1985. Die prediking van Vader, Scun en Heilige Gees. (In Van der Walt, J.J.

"God aan die woord". Potchefstroom : Dept. Diakoniologie, PU vir CHO. p. 29-40.)

RIDDERBOS, J. 1949. De kleine profeten. Obadja tot Zefanja. Vol. II. Kampen : Kok.

STRATHMANN, H. 1967. martus kll. (In: Kittel, G., red. TDNT. Vol. 4. Grand Rapids : Ecrdmans.)

SIMPSON, C.A. 1952. The book of (jenesis. (In Interpreter's Bible. Nashville : Abingdon.) 
TASKER, R V S. 1972. The gospel according to St. John. London: Tyndale.

TKK

kyk

TUSSENKERKLIKE KOMMISSIE (TKK), 1982-1989. Handelinge van die Tussenkerklike Kommissic van die dric Afrikaanse susierskerke. Decl III.

VAN DER WOUDE, A.S. 1974. chrio ktl. (In Kiltel, G., red. TDNT. Vol. 9. Grand Rapids : Eerdmans.) VAN GRONIN(iEN, G. 1990. Messianic revelation in the Old Testament. Grand Rapids : Baker House. VAN SELMS, A. 1967. Genesis. Vol. I. Nijkerk : Callenbach.

VAN LEEUWEN, J.A.C. 1951. Markus. Kampen : Kok.

VERHOEF, P.A. 1990. Calvyn oor dic Messiasverwagting in dic Ou Testament. NGTT, 31(1):112-117. Maart.

VON RAD, G. 1963. Genesis. London : SCM.

VISCHER, W. 1946. Das Christuszeugnis des Alten Testaments. Vol. I. Zurich : Evangelischer Verlag WEISER, A. 1962. The Psalms (OTL). London: SCM.

WENHAM, GJ. 1987. Genesis 1-15. Waco: Word.

WESTERMANN, C. 1969. Isaiah 40-66. (Old Testament Library.) Tr. D.M.G. Stalker. London : SCM. ZIMMERLI, W. 1967. pais theou. (In Kittel, G., red. TDNT. Vol. S. Grand Rapids: Eerdmans.) 
